\title{
КЛИНИЧЕСКАЯ ХАРАКТЕРИСТИКА ОСТРОГО ИНФАРКТА МИОКАРДА У БОЛЬНЫХ САХАРНЫМ ДИАБЕТОМ БУРЯТСКОЙ ПОПУЛЯЦИИ
}

\author{
'Бардымова Т.П., ${ }^{2}$ Цыреторова С.С., ${ }^{3}$ Донирова О.С.
}

\begin{abstract}
'Иркутская государственная медицинская академия последипломного образования — филиал ФГБОУ ДПО РМАНПО Минздрава России, Иркутск

гоГБУз Иркутская городская клиническая больница №3 Минздрава Иркутской области, Иркутск ЗГАУЗ «Республиканская клиническая больница им. Н.А. Семашко» Минздрава Республики Бурятия, Улан-Удэ
\end{abstract}

ЦЕЛЬ: изучить клинические особенности острого инфаркта миокарда у больных сахарным диабетом бурятской попУляции.

МАТЕРИАЛЫ И МЕТОДЫ: проведен ретроспективный анализ 2329 медицинских карт больных с установленным диагнозом острый инфаркт миокарда (ОИМ) за пятилетний период. Все больные проходили стационарное лечение в отделении неотложной кардиологии Республиканской клинической больницы имени Н.А. Семашко г. Улан-Удэ (Республика Бурятия).

PЕЗУЛЬТАТЫ: среди пациентов с ОИМ больные сахарным диабетом 2 типа (СД 2 типа) и нарушенной толерантностью к глюкозе (НТГ)/нарушенной гликемией натощак (НГН) составили 48\% (СД 2 типа 532 чел. и НТГ/НГН - 574 чел.) и 52\% - пациенты с ОИМ без нарушений углеводного обмена (НУО) (1223 чел). Больные разделены на две группы по этнической принадлежности: I - европеоидная популяция - 1747 чел. (75\%) и II - бурятская популяция - 582 чел (25\%). В I группе было 833 пациента

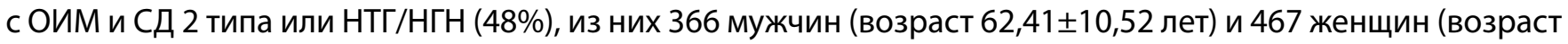

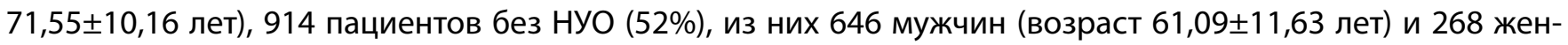

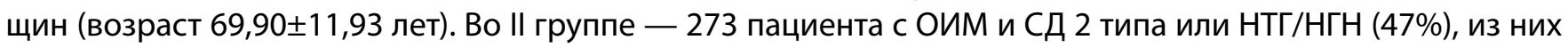

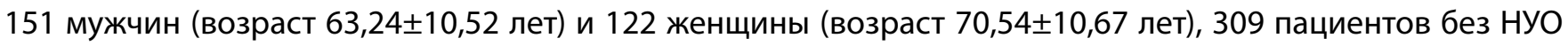

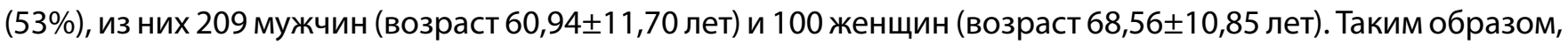
в группе больных ОИМ и СД или НТГ/НГН европеоидной популяции было больше женщин (56\%), а среди бурят с ОИМ и СД или НТГ/НГН превалировали мужчины 55\% (p<0,05). По гендерному составу больные ОИМ без НУО европеоидной и бурятской популяций не отличались ( $>>0,05)$. Как в европеоидной, так и в бурятской популяции у мужчин с СД или НТГ/НГН инфаркт зарегистрирован в более молодом возрасте относительно женщин ( $<<0,05)$. Сравнительный анализ показал, что уровень общего холестерина (OX) выше у больных ОИМ и СД или НТГ/НГН европеоидной популяции относительно бурят с диабетом или

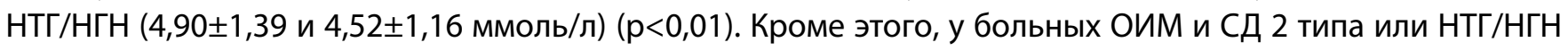
европеоидной популяции концентрация липопротеинов низкой плотности (ЛПНП) выше по сравнению

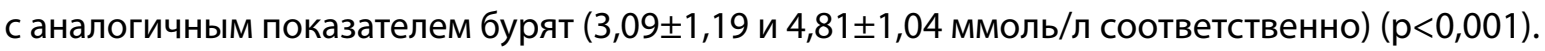

ВЫВОдЫ: у больных СД 2 типа или НТГ/НГН бурятской популяции ОИМ чаще зарегистрирован у мужчин, чем у женщин. У бурят с ОИМ и НУО дислипидемия (ОХ и ЛПНП) менее выражена относительно европеоидной популяции.

КЛЮЧЕВЫЕ СЛОВА: сахарный диабет; инфаркт миокарда; этнические особенности. 